\title{
Electric Filed Intensity of the Lightning Strikes on Lightning Air Terminals Installed on Building Structures
}

\author{
Irshad Ullah $^{1}$, MNR Baharom ${ }^{2}$, H. Ahmad, H.M. Luqman ${ }^{3}$, Zainab Zainal ${ }^{4}$ \\ ${ }^{1,2,3}$ Department of Electical Power Engnieering, Faculty of Electrical and Electronic Engineering, 86400, \\ University Tun Hussein Onn Malaysia, Parit Raja, Batu Pahat, Johor, Malaysia \\ ${ }^{4}$ School of Electrical and Electroics Engineering, University Science Malaysia, Malaysia
}

\begin{tabular}{l} 
Article Info \\
\hline Article history: \\
Received, Jun 14, 2017 \\
Revised, Aug 30, 2017 \\
Accepted, Sep 14, 2017 \\
\hline
\end{tabular}

\section{Keyword:}

Electric field

Geometrical structures

Lightning air terminal,

Lightning strike pattern

\begin{abstract}
Lightning activities are growing up rapidly with global warming. It can affect anything on the earth. All the constructed buildings need proper protection from the harmful effect of lightning. Lightning strike points on different geometrical shapes have been investigated. Lightning strike distribution of different building structure is very important to be studied. In order to analyse the maximum effect of lightning strike pattern is obtained of different air terminals installed on scaled building structures. High voltage impulse generator is used in order to get the impulse voltage. Different numbers of air terminals have been applied to all the shapes in order to see the lightning strike points. Electric field is obtained in order to see its minimum and maximum effect on the entire building structure. Interestingly the phenomenon of lightning air terminal bypasses has been proved in this paper.
\end{abstract}

Copyright () 2017 Institute of Advanced Engineering and Science. All rights reserved.

\section{Corresponding Author:}

Irshad Ullah,

Departement of Electrical and Electronics Engineering,

University Tun Hussein Onn Malaysia ,

86400 Parit Rja, Batu Pahat, Johor, Malaysia.

Email: Irshadullah95@yahoo.com

\section{INTRODUCTION}

Cloud to ground lightning strike is one the most dangerous type of lightning strike. This paper mainly deals with the effect of lightning on different geometrical structures. Lightning flashes in the form of impulse voltage is produced as impulse voltage experimentally by impulse generator.

Lightning can damage building structures and can catch fire in a particular area. Therefore, the buildings are protected by conducting system installed on the buildings which have to be safe from lightning stroke [1]. For lightning protection systems different standards have been developed. Among them BS 6651 is a British standard, NFPA 780 is American and IEC 6104,6235-1-2 discuss the installation of protection system in buildings in detail [2]. Lightning flashes per day (iso keraunic level) is an important element for a given area in order to calculated lightning flash density for a particular area. The number of lightning flash per day is calculated per area not in kilometers which produces an uncertainty in minds. There are only few countries which have the lightning detection system [3]. Early warning about the lightning can reduce the chances of damages and casualties. The early information can be real time monitored. Although there is no such system existing which can provide $100 \%$ correct information about lightning occurrence in high lightning flash density areas [4]. Protection of building can protect the electronic equipment and human casualties as it can damage anything on the earth during intensive lightning strike. 


\section{LIGHTNING ATTACHEMENT}

In order to provide effective protection against lightning, it is very important to calculate the intensity of electric field produced due to lightning stroke. Besides it is necessary to define the probability of lightning on particular structure as well [5]. Rolling sphere method can guide us to the possible lightning strike on building having lightning protection system however it cannot show that how much will be the probability for the particular place to be hit by the lightning. To calculate this, a computer based programing method is given in [6]. To make sure the placement of lightning air terminal on accurate place in order to see more lightning strike probability on structure, Abhay Srivastava and Mrinal Mishra proposed an algorithm. This provide more information about the lightning strike probability on a particular building [7].

\section{PERFORMANCE OF FRANKLIN ROD}

Franklin rod is the major device which, is installed on building for the lightning protection purpose. For more than 250 years franklin rod is used as a protection device [8]. For the protection of any structure lightning rod geometry is an essential element. When rods of height of $6.4 \mathrm{~m}$ above the ground with the same distance from each other it has been shown that the rods with blunt tips are good receptor of lightning stroke [9].

Bypass phenomenon of lightning air terminal (LAT) is now a days an issue of interest. LAT acts as lightning attraction device which then produce an electric field around and can therefore, the LAT is bypassed. Due to this the lightning can produce side flashes which can damage the building. To study this phenomenon few surveys and the lightning flash damages been studying on different buildings when then buildings been installed with lightning protection system (LPS) [10], [11].

\section{METHODLOGY OF WORK}

To analyze the lightning strike points on different geometrical structures $100 \mathrm{k} \mathrm{V}$ impulse generator (HV 19500) was used in order to produce high voltage impulse. Four different geometrical structures are tested. These structures are square, rectangular, gable and circular. The numbers of air terminal are different depending on the building structure's roof. The structures are scaled as it is difficult to test the actual building model in laboratory. The scaled models are tested in high voltage lab. The impulse generator is working on high voltage and low current therefore the buildings structures are tested on high voltage and low current according to available facilities in high voltage lab. The structures are rescaled according to [12]. The air gap between the tip of the rod and the top electrode is kept $3 \mathrm{~cm}$ constant for every structure. All the tests are performed on ambient condition for temperature and humidity. For all the structures 30 flashes have been applied to see flashes on different points. Installation of the lightning air terminal is according to [13], [14].

The average parameters of the weather conditions are:

a. Impulse voltage $=81.89 \mathrm{kV}$

b. $\quad$ Temperature $=28.13^{0} \mathrm{C}$

c. $\quad$ Pressure $=1.03 \mathrm{~Pa}$

d. Humidity $=70.7 \%$

The experimental procedure is consists of the inverted rod- plane method. The top electrode represents the cloud while the scaled shape represents the building of any height.

\section{EXPERIMENTAL RESULTS}

Experimental results show the lightning strike pattern on different building shapes. The lightning attraction is varies with changing in geometrical shape. The experimental results show the distribution of lightning strike on different air terminals. During lighting impulse electric field is produced. For all the tested shape the electric field is also simulated in order to observe the electric field strength on every air terminal.

\subsection{Lightning Strike Pattern of the Square Shape}

Square shape has four air terminals. The lightning strike is distributed on all air terminals with different number of lightning flashes. The air gap is same. All the ambient conditions are kept the same. Table 1 shows the number of strikes distribution on each air terminal. Similarly Figure 1 shows Lightning flash on different air terminals of square shape.

Table1 represents the strike distribution on the installed air terminals on the square geometrical shape. The number of lightning strikes is different on the air terminals.

Figure1 shows the lightning strike distribution on square shape. All the air terminals have been struck by the lightning strike. 
Table 1. Lightning strike pattern on square building structure

\begin{tabular}{ccccc}
\hline \multicolumn{5}{c}{ Stricken air terminal } \\
\hline Air terminal & T1 & T2 & T3 & T4 \\
No. of strikes & 10 & 8 & 7 & 5 \\
\hline
\end{tabular}
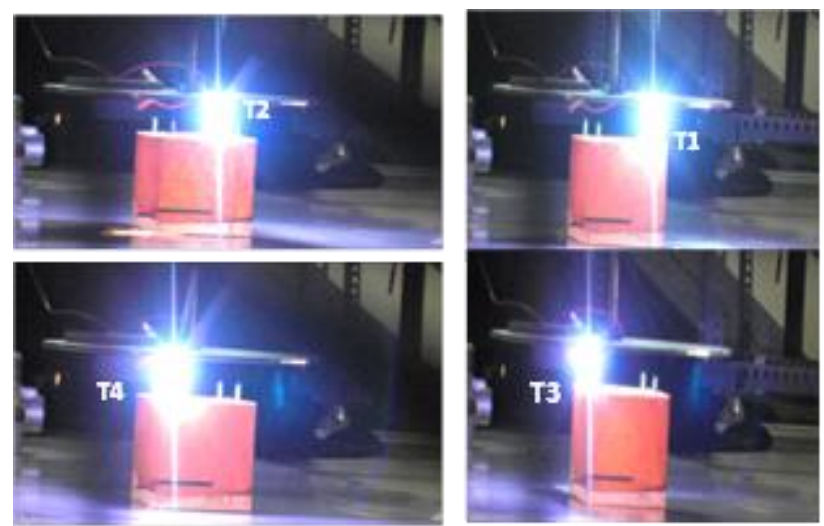

Figure 1. Lightning strike distribution on square shape

\subsection{Electric Field Intensity on the Air Terminals of the Square Building Structure}

When the impulse voltage is applied to the test object the most important thing is this process is the electric field produced. As the break down occurs on the air terminal electric field is produced around the air terminal. This electric field can affect the surrounding of the object. The value of the simulated electric field on the given voltage is given in Figure 2.

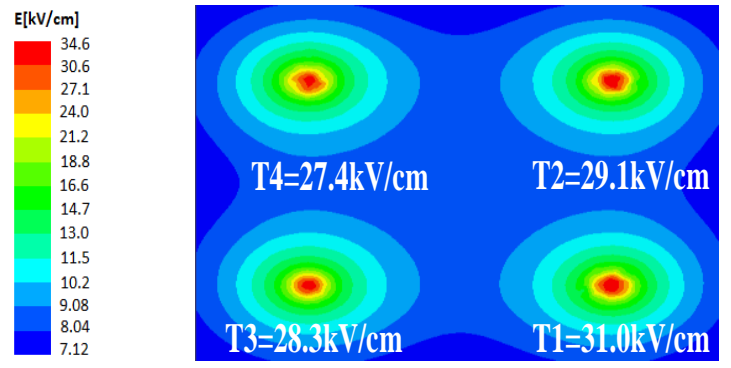

(a)

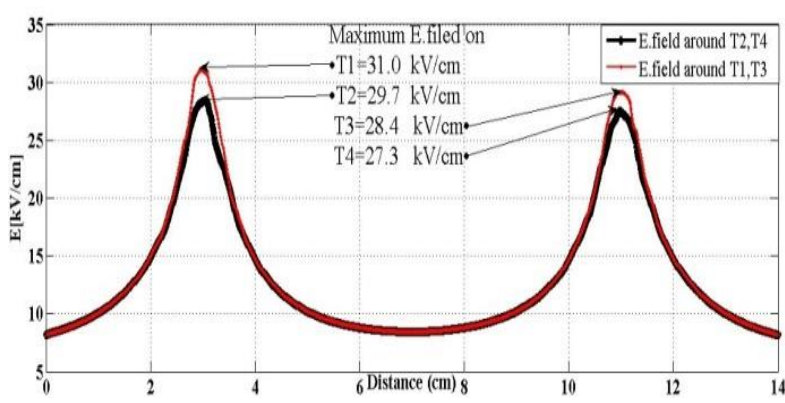

(b)

Figure 2. (a) Electric field plot around air terminal, (b) graphical presentation of the maximum electric field on the air terminal

Where

a. $\quad$ T1 $=$ Lightning air terminal 1

b. $\quad \mathrm{T} 2=$ Lightning air terminal 2

c. $\mathrm{T} 3=$ Lightning air terminal 3

d. $\quad$ T4 = Lightning air terminal 4

Figure 2(a) shows the electric field intensity on each terminal while Figure 2(b) represents the graphical representation of the electric field value around each air terminal. It can be seen that $\mathrm{T} 1$ which is on the right side can receive more electric field. This shows that the value of the electric is different as the number of strikes on the air terminals. It can be seen that the electric field is higher on the air terminal, which attracts more lightning flashes. The simulation of the electric field can make sure that if the lightning strikes are more 
on the air the air terminal the respective electric field will be higher. The same phenomenon will also be proven for the next different building structures.

\subsection{Lightning Strike Pattern of the Rectangular Building Structure}

The rectangular scaled building structure provided 6 air terminals on the corner and the edges. The impulse voltage is applied in order to analyse the pattern of the lightning strike on the given structure. Table 2 indicates the strike distribution on different air terminals of the rectangular shape. Figure 3 shows the strike distribution on the different air terminals. The air terminals on the corners receive more lightning flashes while the edges will receive comparatively less as the lightning has more tendencies to be attached to the corners.

Table 2. Lightning strike pattern on rectangular building structure

\begin{tabular}{lllllll}
\hline & \multicolumn{7}{c}{ Stricken on air terminal } \\
\hline Air terminal & T1 & T2 & T3 & T4 & T5 & T6 \\
No. of strikes & 7 & 6 & 4 & 2 & 6 & 5 \\
\hline
\end{tabular}

Table 2 expresses the number of strikes on the air terminals installed on rectangular building. The numbers of strikes are distributed over all the air terminal installed on the mentioned structure.
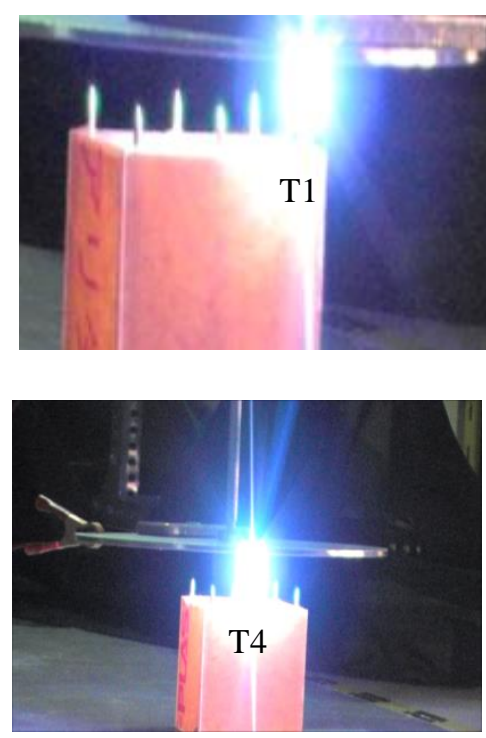
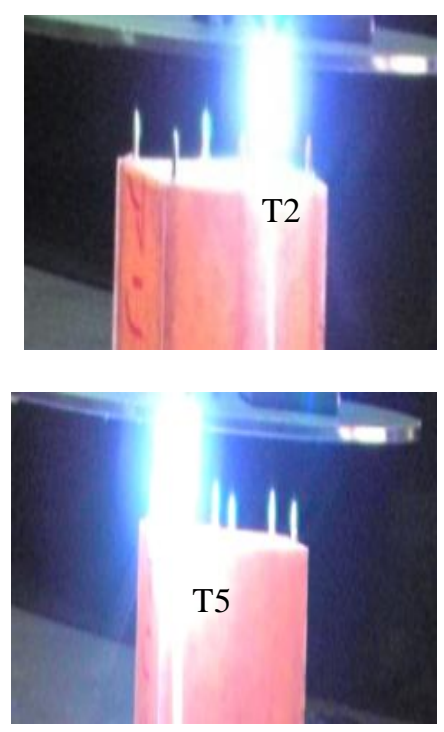
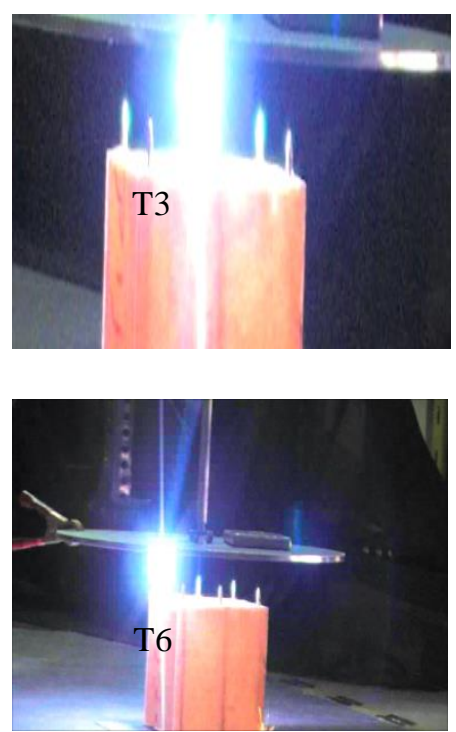

Figure3. Lightning strike distribution on rectangular shape

Figure 3 indicates the strike distribution pattern on rectangular shape. It can be seen that all the air terminals have been struck by the lightning flash. Which shows the striking pattern and most probable striking point of the lightning strikes.

\subsection{Electric Field Intensity on the Air Terminals of the Rectangular Building Structure}

Rectangular shape has corners as well as edges. From the simulation is can be seen in Figure 4 that the value of electric field is higher at the corners while it will be less at the edges. Similarly it can be shown that the air terminal attracts more lightning will have more electric field. The graphical plot can show the maximum electric field on every air terminal.

Figure 4(a) has an interesting results which proved the phenomenon discuss in ref. 13 and 14. It is clear from the field plot that the electric field intensity is higher on the corners and edges and is almost zero at the middle of rectangular shape. This increase in electric filed intensity on the corner and edges can produce bypasses of LAT and the entire building can be damaged. It has be proved that in certain building 
shapes the maximum chances of bypasses are from the installed LPS itself. Therefore LAT not only use for protection but it also attract the lightning.

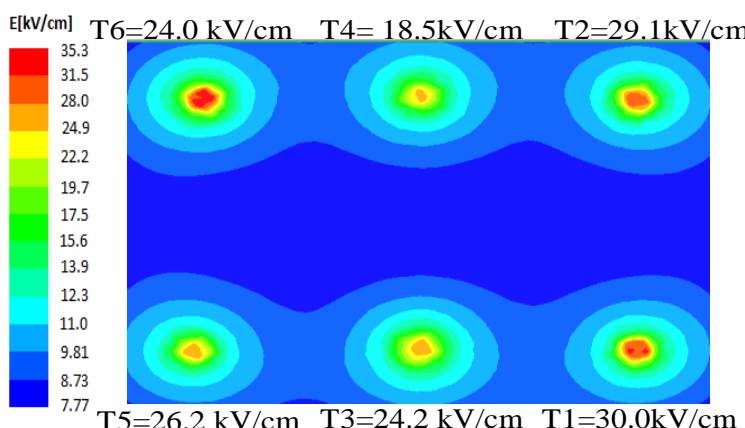

(a)

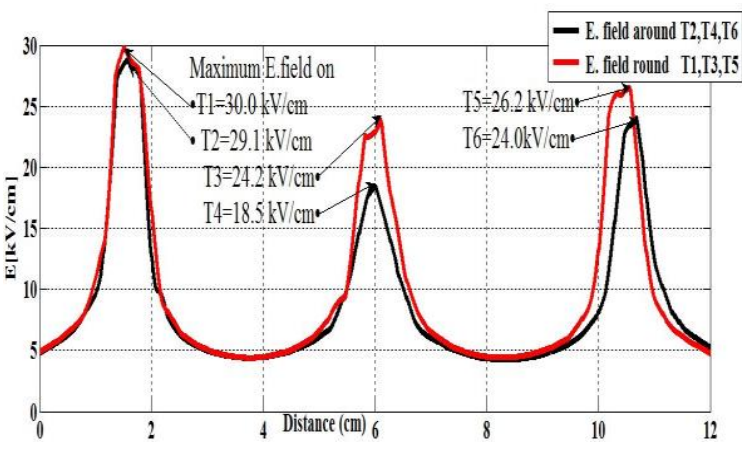

(b)

Figure 4. (a) Shows the plot of the electric field distribution around the air terminals and on the whole surface of the rectangular shape. The high and low intensity of the electric field can be seen clearly from the figure,

(b) shows the graphical plot with the maximum value of electric field on the air terminal

\subsection{Lightning Strike Pattern of the Gable Building Structure}

Gable shape provided 3 lightning air terminals according the standard mention in methodology section. All the air terminals are in the same line. The ambient conditions for the gable shape are the same. The lightning strike pattern is observed on all the three terminals. Table 3 shows the number of lightning strike on the entire terminals and Figure 5 represents the strike distribution on all the air terminals. Terminal 2 is hit the least as it is in the middle and most of the strikes are on the corners.

Table 3 represents the number of strike on the air terminals installed on gable shape. Three air terminals have the strike points and the number of strikes on each terminal is shows in the table. Figure 4 shows the strike distribution on each air terminal of the gable shape.

Table 3. Lightning strike pattern on gable building structure

\begin{tabular}{llll}
\hline & \multicolumn{4}{l}{ Stricken air terminal } \\
\hline Air Terminal & T1 & T2 & T3 \\
No. of strikes & 14 & 3 & 13 \\
\hline
\end{tabular}
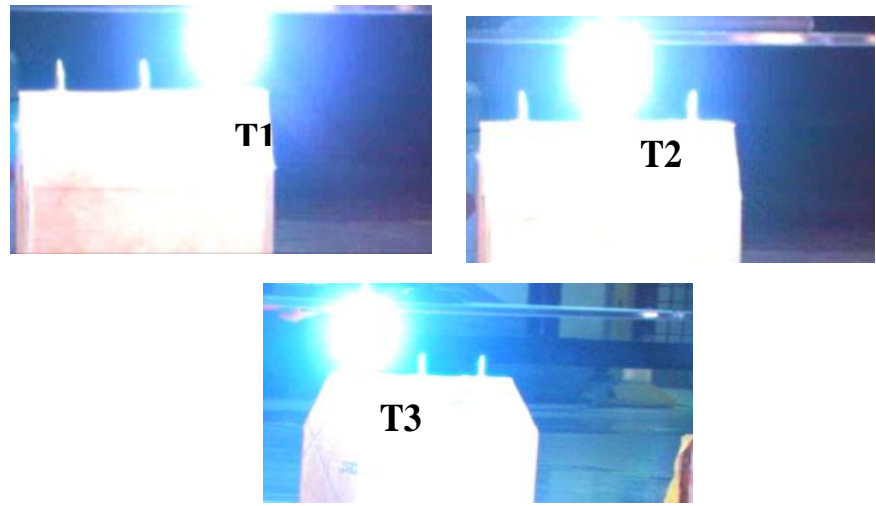

Figure 5. Lightning strike distribution on rectangular shape

From Figure 5, it is clear that the lightning flash has been observed on all the three air terminal. All the air terminals have been struck which shows that the distributions of lightning strikes take place on all the air terminals. 


\subsection{Electric Field Intensity on the Air Terminals of the Gable Building Structure}

Gable is a little different shape than other geometrical structures and therefor it can be seen the corner and edges also in different arrangement from other shapes. However in this shape the numbers of air terminal are needed less and it can provide protection to all the building as shown in Figure 6.

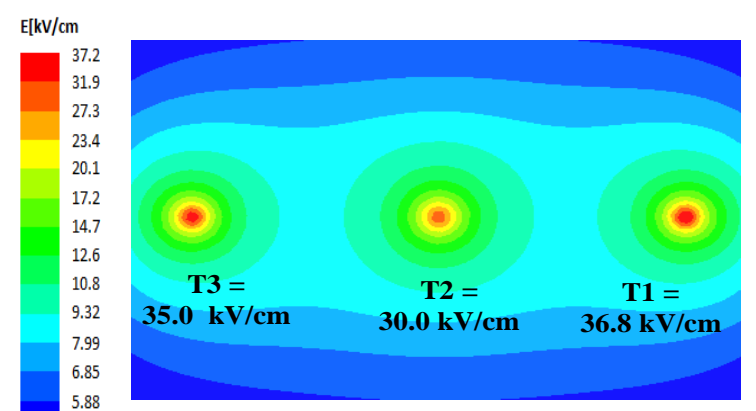

(a)

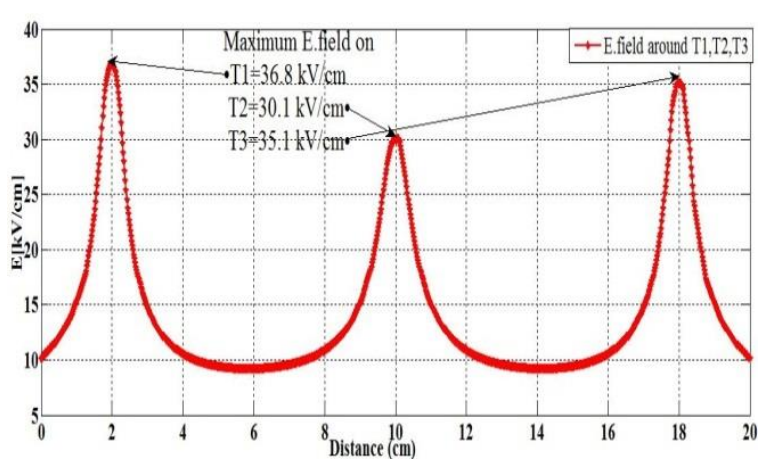

(b)

Figure 6. (a) Shows the plot of electric field on the whole surface of the building structure, while (b) represents the maximum electric field value on every air terminal, when lightning strike an air terminal the maximum electric field is on the tip of rod

\subsection{Lightning Strike Pattern of the Circular Building Structure}

Circular shape has 4 air terminals installed on it. Interestingly circular shape has no corners. The lightning will be attached by the air terminals installed on the edges. The lightning flashes attachment takes place by all the air terminals which show that the building structure designed is quite accurate. Similar to other building shapes the ambient conditions are same throughout the experimental procedure during testing the object. Table 4 explains the number of strikes on each air terminal of the given shape. The strike pattern is given in Figure 7 which shows the strike distribution on all the air terminals.

Table 4. Lightning strike pattern on circular shape

\begin{tabular}{lllll}
\hline & \multicolumn{4}{c}{ Stricken air terminal } \\
\hline Air terminal & T1 & T2 & T3 & T4 \\
No. of strikes & 9 & 8 & 7 & 6 \\
\hline
\end{tabular}

Table 4 shows the number of strikes on the circular shape. The shape consists of 4 air terminal and all the air terminals receive the lightning flashes.
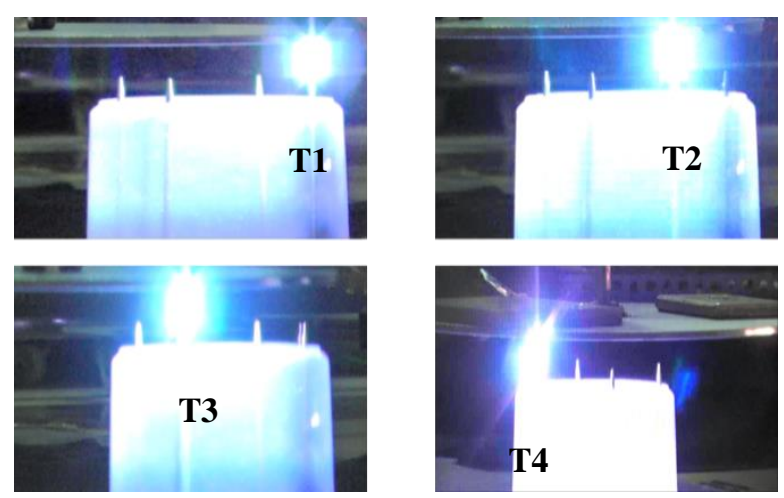

Figure 7. Strike distribution on circular shape 
From Figure 7 it is obvious that lightning flashes are attracted by all the air terminals. Some of the air terminals receive more flashes while some receive less in number.

\subsection{Electric Field Intensity on the Air Terminals of the Circular Building Structure}

Circular shape can be found everywhere. Its protection from lightning is very important. When lightning strikes the air terminal installed on the circular shape it produce the electric field which can affect the surround of the building. The electric field effect is shown in Figure 8.
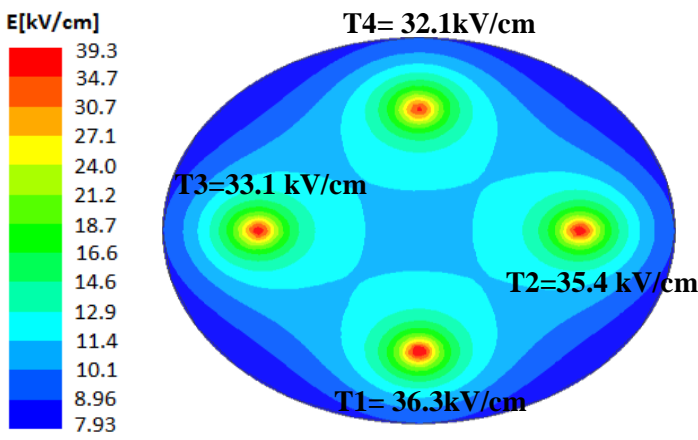

(a)

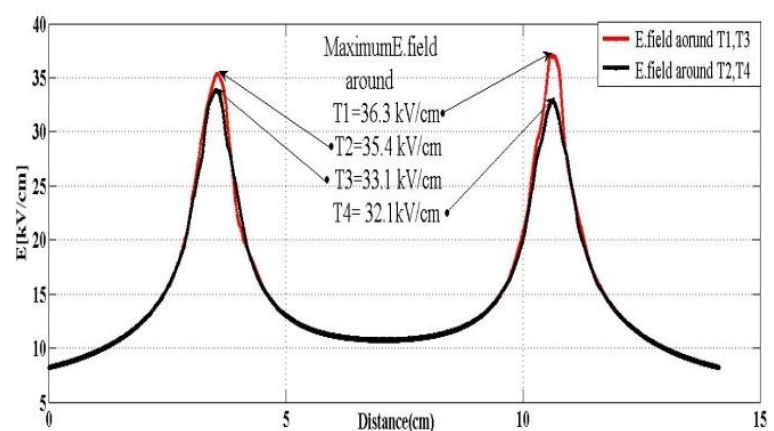

(b)

Figure 8. (a) Electric field plot on the circular shape, (b) maximum electric field on air terminals

Figure 8(a) explains the electric field plot around all the air terminals and on the surface of the building shape. The value of electric filed is given for every air terminal (b) indicates the graphical representation of the electric field values. It can show the maximum and minimum value of the electric field around the air terminal installed. In circular shape maximum electric field is on the front air terminal which is terminal 1.

\section{DISCUSSION}

Lightning strike pattern on different scaled building structure is elaborated. A lightning strike point on different roof structures is an essential element for the protection of buildings. Strike points can help for the probability of lightning strike on each structure. The scaled structures are tested on the Malaysia ambient condition. The experimental process also ensures the maximum lightning strikes on the particular air terminal of different shapes. The air terminal arrangement is according to the standard. During lighting strike the most important element is the generation of electric field. Electric field can affect the entire building as well as the surrounding environment. Therefore, it is very important to observe its effect on the surface of the building and on the installed air terminal. This paper also provides the electric field simulation. It shows the maximum and minimum value of the electric field. The value of the electric field ensures the most probable point which could be struck of the lightning strike. Keeping in consideration the electric field effect the installed air terminal can b placed on the proper position as well as the building could be given more attention on the effected point to be protect more accurately and according to suggestions provide by the research work done.

\section{CONCLUSION}

The work done in this paper is experimental. The impulse generator used is high voltage and low current according to the available facilities in high voltage laboratory. The work has been done for the detail analysis of lightning strike points on different roof structure. The behavior is different for different structures. It has been proved experimentally that lightning strike points are mostly on the corner and few of them also strikes on edges which can strengthen the phenomenon of bypasses. Although lightning has random behavior but still it can be observed the lightning strike probability is different for different roof structure. The electric field value has been simulated in order to make sure that protection is required on the most stricken part of the building. It is obtained that electric field produced is not up to the limit in which a man can be survived with if the building is struck by the lightning. This paper proved the bypass phenomenon of LAT. It can be seen the rectangular building can get more bypasses as the electric field is higher on the corner and edges. 
The results can leads the researchers to provide proper protection to the effected point. The lightning strike distribution is obtained on all the air terminal which can proved the most probable points to be hit.

\section{ACKNOWLEDGEMENT}

Authors would like to thanks UTHM for supporting this research work. ORICC of the UTHM is highly acknowledged and appreciated for supporting financially under the vote no. u563. Faculty of Electrical and Electronics engineering is also appreciated for the moral support.

\section{REFERENCES}

[1] G. S.Ait Amar andBerger, "A Model of Protection of Earthed Structures by Means of Lightning Rod Conductors," 2005.

[2] M. Abu et al., "An Overview of Lightning Air Terminal : Past, Present , and Future," SCOReD, pp. 27-28, 2006.

[3] C. Gomes and M. Z. a. A. Kadir, "A theoretical approach to estimate the annual lightning hazards on human beings," Atmos. Res., vol. 101, no. 3, pp. 719-725, Aug. 2011.

[4] H. Tang, "Study on Lightning Early Warning Information in the Application of Lightning Risk Assessment," pp. 127-130, 2014.

[5] Y. Beck, "3d lightning strikes probability program,” 2008, pp. 368-372.

[6] A. Kern, C. Schelthoff, and M. Mathieu, "Probability of lightning strikes to air-terminations of structures using the electro-geometrical model theory and the statistics of lightning current parameters," Atmos. Res., vol. 117, pp. 2-11, Nov. 2012.

[7] A. Srivastava and M. Mishra, "Positioning of lightning rods using Monte Carlo technique," J. Electrostat., vol. 76, pp. 201-207, Aug. 2015.

[8] R. Hartono Zainal Abidin, Ibrahim, "Conventional and Un-conventional Lightning Air Terminals : An Overview," 2004, pp. 1-39.

[9] F. D'Alessandro, “On the optimum rod geometry for practical lightning protection systems," J. Electrostat., vol. 65, no. 2, pp. 113-121, Feb. 2007.

[10] Z. A. Hartono and R. Ibrahim, "A database of lightning damage caused by bypasses of air terminals on buildings in Kuala Lumpur, Malaysia," in VI International Symposium on Lightning Protection, 2001, no. February.

[11] Z. A. Hartono and I. Robiah, "A study of non-conventional air terminals and stricken points in a high thunderstorm region," Light. Prot. (ICLP), 2000 Int. Conf.

[12] J. L. Bermudez, F. Rachidi, A. Chisholm, M. Rubinstein, M. Hussein, and S. Chang, "On the Use of Transmission Line Theory to Represent a Nonuni- form Vertically-Extended Object Struck by Lightning,” pp. 501-504, 2003.

[13] A. R. Reserved, NFPA 780 Standard for the Istallation Lightning Protection System. 2006, pp. 1-165.

[14] G. Principles and R. Management, BS EN / IEC 62305 Lightning protection standard Key points Guide to BS EN/ IEC 62305, vol. 44, no. 0. 2008, pp. 1-107.

\section{BIOGRAPHIES OF AUTHORS}
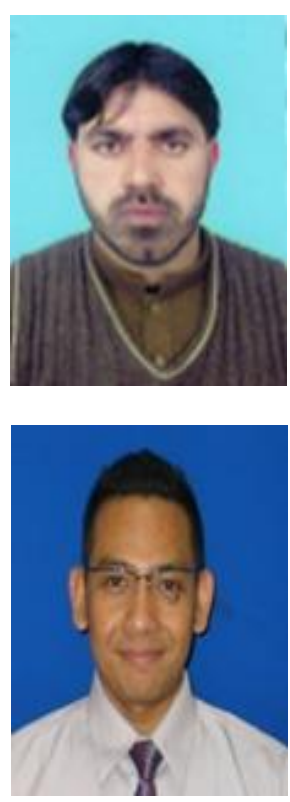

Irshad Ullah was born in District Dir KP, Pakistan on January 5, 1985. He received the Bachelor's Degree in Electrical Engineering from the Cecose University Peshawar and his Master's in Electrical Engineering from Stafford Shire University, UK in 2010 and 2013 respectively. Currently he is pursuing Ph.D. in Electrical Power Engineering from Universiti Tun Hussein Onn Malaysia.
Md Nor Ramdon Bin Baharom was born in Kuala Lumpur, Malaysia in August 1978. He received the B.E. degree in Electrical and Electronic Engineering from School of Computing, Creative Technologies \& Engineering, Leeds Metropolitan University, United Kingdom in 2004. He received the PhD degree from Electrical Energy and Power Systems Group of the School Of Electrical and Electronic Engineering at the University of Manchester in 2010. He is currently working as a lecturer in Department of Power Electrical Engineering of the Faculty of Electrical and Electronic Engineering, Universiti Tun Hussein Onn Malaysia (UTHM), Malaysia. His major research interests include high-voltage insulations, overhead-line design, lightning structure protection, electrical environmental interference impact, composite insulators and flashover of contaminated insulators. 

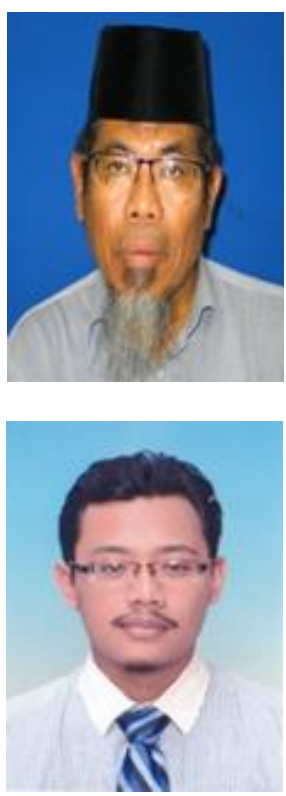

Luqman Hakim bin Mahmod was born in Perak, Malaysia on October 29, 1988. He received the Bachelor's Degree in Electrical Engineering and his Master's in Electrical Engineering from Universiti Tun Hussein Onn Malaysia in 2010 and 2012 respectively. Currently he is pursuing Ph.D. in Electrical Power Engineering from Universiti Tun Hussein Onn Malaysia.

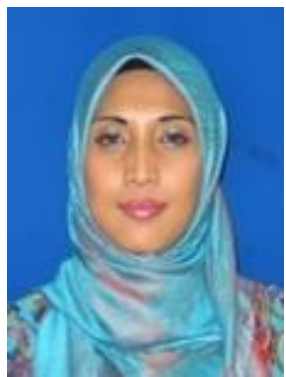

Zainab Zainal was born in Perak, Malaysia in June, 1982. She received the B. E. degree in electrical and electronic engineering from the University of Manchester in 2005 and M.S. degree in Electronics System Design from Manchester Metropolitan University in 2009, respectively. She was working as a lecturer in Centre of Diploma Study, Universiti Tun Hussein Onn Malaysia (UTHM), Malaysia from 2011-2015. She is currently working towards the Ph.D degree in the School of Electrical and Electronic Engineering student of the University of Science, Malaysia. 